\title{
Photosynthesis and growth of young grapevines intercropped with native grasses in soils contaminated with copper
}

\author{
L. De Conti ${ }^{1}$ G.W. Melo ${ }^{2}$, C.A. Ceretta ${ }^{1}$, C.P. Tarouco 3 , A.C.R. Marques ${ }^{3}$, F.T. Nicoloso ${ }^{3}$, \\ A. Tassinari ${ }^{1}$, T.L. Tiecher ${ }^{1}$, S. Cesco ${ }^{4}$, T. Mimmo ${ }^{4}$ and G. Brunetto ${ }^{1, a}$
}

\begin{abstract}
${ }_{1}^{1}$ Department of Soil Science, Center of Rural Sciences, Federal University of Santa Maria, Santa Maria, Rio Grande do Sul, Brazil; ${ }^{2}$ Brazilian Enterprise for Agricultural Research, Embrapa Uva e Vinho, Bento Gonçalves, Rio Grande do Sul, Brazil; ${ }^{3}$ Department of Biology, Center of Natural and Exact Sciences, Federal University of Santa Maria, Santa Maria, Rio Grande do Sul, Brazil; ${ }^{4}$ Faculty of Science and Technology, Free University of Bozen-Bolzano, Bolzano, Italy.
\end{abstract}

\begin{abstract}
High copper $(\mathrm{Cu})$ contents in vineyard soils due to long-term foliage-defense program based on $\mathrm{Cu}$-containing fungicides may cause physiological and nutritional disorders in young grapevines, limiting plant growth and in some cases also compromising plant survival. This problem is particularly evident in viticultural areas of southern Brazil. Therefore, the study aimed to assess if the intercropping of grapevines with native grasses of southern Brazil can contribute to limit the soil $\mathrm{Cu}$ availability and thus the onset of toxicity symptoms (i.e., impairment of photosynthetic and growth parameters). In order to do this, we collected soil samples in the natural grassland of the Pampa Biome (southern Brazil). The samples were airdried, the acidity, phosphorus and potassium levels were corrected and the samples were consequently incubated. We used three $\mathrm{Cu}$ levels - control (i.e., no $\mathrm{Cu}$ addition), 40 and $80 \mathrm{mg} \mathrm{Cu} \mathrm{kg}^{-1}$. Such $\mathrm{Cu}$ levels are normally found in vineyard soils of the region. The experimental design was completely randomized with three replications. At each $\mathrm{Cu}$ level, we set up three combinations of monocropping (Grapevine), and intercropping with Paspalum plicatulum Michx. (Grapevine + Paspalum plicatulum) and Axonopus affinis Chase (Grapevine + Axonopus affinis). In the intercropped treatments, two grass seedlings were transplanted into each experimental unit, 35 days before transplanting the grapevines. The experiment was conducted for 70 days. At 41 days after transplanting the grapevines, gas exchange (IRGA) was measured. At 70 days, plant height and total dry matter yield were determined and the relative growth rate was quantified. The addition of $\mathrm{Cu}$ caused phytotoxicity in the single crop (Grapevine), reducing photosynthetic carbon assimilation and plant growth. The cultivation of young grapevines intercropped with native grasses, especially Paspalum plicatulum Michx., promoted the growth of the grapevines in the control soil as well as in the moderately $\mathrm{Cu}$-contaminated soils. This indicates that maintaining native vegetation in young vineyards can reduce $\mathrm{Cu}$ toxicity to transplanted grapevines.
\end{abstract}

Keywords: cover crops, phytotoxicity, heavy metals, biome pampa, Vitis vinifera

\section{INTRODUCTION}

The application of cupric fungicides for the control of foliar diseases in grapevines may lead to an increase in copper $(\mathrm{Cu})$ contents in vineyard soils (Miotto et al., 2014; Cambrollé et al., 2015; Brunetto et al., 2016). High levels of Cu can cause toxicity to young grapevines planted in soils of eradicated old grapevines and to the cover crops that co-inhabit these vineyards (Miotto et al., 2014).

Copper is a micronutrient to plants, but its excessive acquisition by roots severely

${ }^{\mathrm{a}} \mathrm{E}-\mathrm{mail}$ : brunetto.gustavo@gmail.com 
compromises plant growth by impairing the functioning of the photosynthetic apparatus, reducing the carbon fixation (Kabata-Pendias, 2011; Cambrollé et al., 2015; Tiecher et al., 2016). The symptoms of phytotoxicity caused by excess $\mathrm{Cu}$ depend on the available fraction in the soil solution and on the plant species; in fact, excess $\mathrm{Cu}$ might trigger different tolerance mechanisms depending on the plant species (Oyuela Leguizamo et al., 2017). Copper-tolerant plants either reduce the $\mathrm{Cu}$ availability in the rhizosphere by complexation reactions due to the release of ions and soluble organic compounds or by preventing $\mathrm{Cu}$ translocation to the shoots accumulating the metal in the root system (mainly in the apoplast) (De Conti et al., 2016; Brunetto et al., 2016). These tolerance mechanisms, can also favor the development of other plants grown in intercropping, due to the reduced bioavailability of the contaminant (Brunetto et al., 2016). Native species, such as the South American native grasslands, have mostly evolved in acidic and nutrient poor soils thanks to the ability of these plants to adapt to the conditions of low nutrient levels and the presence of toxic elements (Pallarés et al., 2005). The characteristics of these species, together with their natural occurrence in vineyards of southern Brazil, suggest great potential for the phytoremediation of these soils. Therefore, the study aimed at assessing if the intercropping of grapevines with native grasses of southern Brazil can contribute to limit the soil $\mathrm{Cu}$ availability and thus the onset of toxicity symptoms (i.e., impairment of photosynthetic and growth parameters).

\section{MATERIAL AND METHODS}

The soil used was a Typic Hapludalf (Soil Survey Staff, 2006) collected at $0-20 \mathrm{~cm}$ in an area of uncultivated grassland located in the Pampa Biome, southern region of Brazil $\left(30^{\circ} 47^{\prime} 23.7^{\prime \prime} \mathrm{S}\right.$ and $\left.55^{\circ} 22^{\prime} 7.3^{\prime \prime} \mathrm{W}\right)$. The physical-chemical characterization of the soil is presented in Tiecher et al. (2016). After the collection, the soil was air dried, homogenized and passed through a $2 \mathrm{~mm}$ mesh sieve. Subsequently, soil acidity has been buffered adding a mixture of calcium carbonate $\left(\mathrm{CaCO}_{3}\right)$ and magnesium carbonate $\left(\mathrm{MgCO}_{3}\right)$ with a 2:1 ratio at a concentration of $0.57 \mathrm{~g} \mathrm{~kg}^{-1}$ soil and applied $40 \mathrm{mg} \mathrm{P} \mathrm{kg}^{-1}$ and $100 \mathrm{mg} \mathrm{K} \mathrm{kg}^{-1}$ of soil, in the form of triple superphosphate and potassium chloride, respectively. The treatments consisted of three $\mathrm{Cu}$ levels: control (i.e., no $\mathrm{Cu}$ addition), and the addition of 40 and $80 \mathrm{mg}$ $\mathrm{Cu} \mathrm{kg}-1$, which are levels usually found in vineyards where grapevines have been grown for approximately 15 and 30 years, respectively (Miotto et al., 2014). The addition of $\mathrm{Cu}$ occurred 50 days after the application of the corrective, by applying a solution of $\mathrm{CuSO}_{4}$. $5 \mathrm{H}_{2} \mathrm{O}$. Subsequently, the soil was incubated again for 115 days, with soil moisture kept at $80 \%$ of the maximum water holding capacity (MWHC).

The experimental design was completely randomized with three replications. The experimental units were pots of $8 \mathrm{~L}$ containing $7 \mathrm{~kg}$ of dry soil. At each $\mathrm{Cu}$ level, we set up three combinations of monocropping (Grapevine), as well as intercropping with Paspalum plicatulum Michx. (Grapevine + Paspalum plicatulum) and Axonopus affinis Chase (Grapevine + Axonopus affinis). In November 2015, we transplanted one grapevine (Vitis vinifera L. 'Paulsen 1103') plant per pot, where it was grown for 70 days. In the intercropped treatments (Grapevine + Paspalum plicatulum and Grapevine + Axonopus affinis), two seedlings to native grasses were transplanted into each pot, 35 days before the transplanting of the grapevines. Soon after the transplanting, we determined the stem diameter at the ground level and the height of the grapevines. At 16 and 48 days after transplanting, we applied 20 and $10 \mathrm{mg} \mathrm{N} \mathrm{kg}^{-1}$ of soil in the form of urea, respectively. In the intercropped treatments, the shoots of the cover crops were cut at $10 \mathrm{~cm}$ (height) and placed on the soil surface every 21 days, totaling three cuts along the cultivation of the grapevines. This management of the native grasses simulates the mowing typically used in managing cover crops in commercial vineyards. Soil moisture was maintained at $70 \%$ of the MWHC during cultivation, with daily weightings and the addition of distilled water when necessary.

At 41 days after transplanting the grapevines, gas exchange was measured in two fully expanded leaves (of the middle region), using an open system infrared gas analyzer (IRGA) (LI-6400XT LI-COR, Inc., Lincoln, NE, USA). Net photosynthetic rate, stomatal conductance, intercellular $\mathrm{CO}_{2}$ concentration, transpiration rate, water use efficiency (WUE) and 
instantaneous carboxylation efficiency (CE) were determined at an ambient $\mathrm{CO}_{2}$ concentration of $400 \mu \mathrm{mol} \mathrm{mol}^{-1}$ at $20-25^{\circ} \mathrm{C}, 50 \pm 5 \%$ relative humidity and a photon flux density of $1000 \mu \mathrm{mol} \mathrm{m}^{-2} \mathrm{~s}^{-1}$. After 70 days of the transplanting, we determined the stem diameter at the ground level and the height of the grapevines in order to estimate the relative growth rate (RGR/day) using the following equation (Sieverding, 1991):

$$
\left(\pi r^{2} \times h\right) / \text { plant age }
$$

where $r=1 / 2$ of the difference between the initial and final stem diameter, and $h=$ the difference between the initial and final height of the grapevines. Afterwards, the grapevines were cut close to the soil surface and the roots were separated from the soil by hand, washed in running tap water to remove soil and then stored for the determination of dry matter (DM) in a forced air oven at $\pm 65^{\circ} \mathrm{C}$, until reaching constant dry matter.

The results obtained were submitted to analysis of variance (ANOVA) using Sisvar software, version 5.6 (Ferreira, 2011), with the following completely randomized bifactorial statistical model:

$$
Y_{i j k}=\mu+C i+Z_{j}+C Z_{i j}+\operatorname{error}(i, j)
$$

where $\mu=$ overall mean of the experiment, $C=$ Cu levels $(i=1,2,3), Z=$ crops systems $(j=1$, $2,3)$ and error $=$ experimental error. When the effects were significant, the means were grouped by the Scott-Knott test at $5 \%$ probability.

\section{RESULTS AND DISCUSSION}

The net photosynthetic rate decreased significantly with increasing $\mathrm{Cu}$ concentration added to the soil in grapevines (monocropping) and in grapevines intercropped with Axonopus affinis Chase (Figure 1). In grapevine intercropped with Paspalum plicatulum Michx., the reduction in the net photosynthetic rate occurred only at the highest $\mathrm{Cu}$ concentration used (80 mg kg-1, Figure 1). This behavior was also observed in stomatal conductance and instantaneous carboxylation efficiency (Figure 1). Furthermore, the intercropped systems had a higher net photosynthetic rate compared to the monocropping system (grapevine): in control and $40 \mathrm{mg} \mathrm{kg}^{-1} \mathrm{Cu}$-treated plants we observed an increase of 38.9 and $97.8 \%$ in grapevine + Paspalum plicatulum Michx., and 38.0 and $46.9 \%$ in grapevine + Axonopus affinis Chase, respectively (Figure 1). At these $\mathrm{Cu}$ levels, stomatal conductance, transpiration rate and instantaneous carboxylation efficiency were also higher in the intercropped systems (Figure 1). Intercellular $\mathrm{CO}_{2}$ concentration and water use efficiency were slightly affected by $\mathrm{Cu}$ and did not differ between the cropping systems (Figure 1). These results show that the excess $\mathrm{Cu}$ compromises the functioning of the photosynthetic carbon assimilation pathway, reducing photosynthetic carbon assimilation. The excess $\mathrm{Cu}$ can further induce the reduction of the concentration of photosynthetic pigments and cause the degradation of the structure and the internal content of the chloroplast through the degradation of the membrane polar lipids (Maksymiec et al., 1995; Cambrollé et al., 2015).

The increase in the efficiency of the photosynthetic apparatus in the intercropped systems of the control and $40 \mathrm{mg} \mathrm{kg}^{-1} \mathrm{Cu}$ treated plants is most likely due to the reduced $\mathrm{Cu}$ bioavailability and/or the increased bioavailability of other essential nutrients (Brunetto et al., 2016). Plant roots release in fact a myriad of compouds (i.e., root exudates) modifying the chemical characteristics of the rhizosphere. For instance, $\mathrm{pH}$ changes and the presence of organic ligands could increase the stable complexation of $\mathrm{Cu}^{2+}$ in the soil solution, thus reducing its bioavailability; such processes would favor plant growth, since the uptake of $\mathrm{Cu}$ by the roots occurs preferentially in the free form (McBride, 1994; De Conti et al., 2016).

Copper affected also plant growth both in terms of height and total dry matter, yet only in the monocropping systems and in the $80 \mathrm{mg} \mathrm{kg}^{-1} \mathrm{Cu}$ treated intercropping systems (Figure 2 ). The intermediate $\mathrm{Cu}$ concentration ( $\left.40 \mathrm{mg} \mathrm{kg}^{-1}\right)$ increased the plant height and total dry matter in the intercropping systems by 221 and $213 \%$ in grapevine + Paspalum plicatulum Michx., and 180 and 143\% in grapevine + Axonopus affinis Chase, respectively. The relative 
growth rate was higher in the intercropped systems compared to the monocropping/grapevine in the control and at the intermediate $\mathrm{Cu}$ concentration (Figure 2). The reduction in grapevine growth at high $\mathrm{Cu}$ levels is probably related to the lower photosynthetic carbon assimilation (Figure 1). Furthermore, the excess $\mathrm{Cu}$ can affect the function of membrane transporters and ion channels, reducing their selective capacity; the resulting nutritional imbalances might also contribute to the reduction of plant growth (Cambrollé et al., 2015).
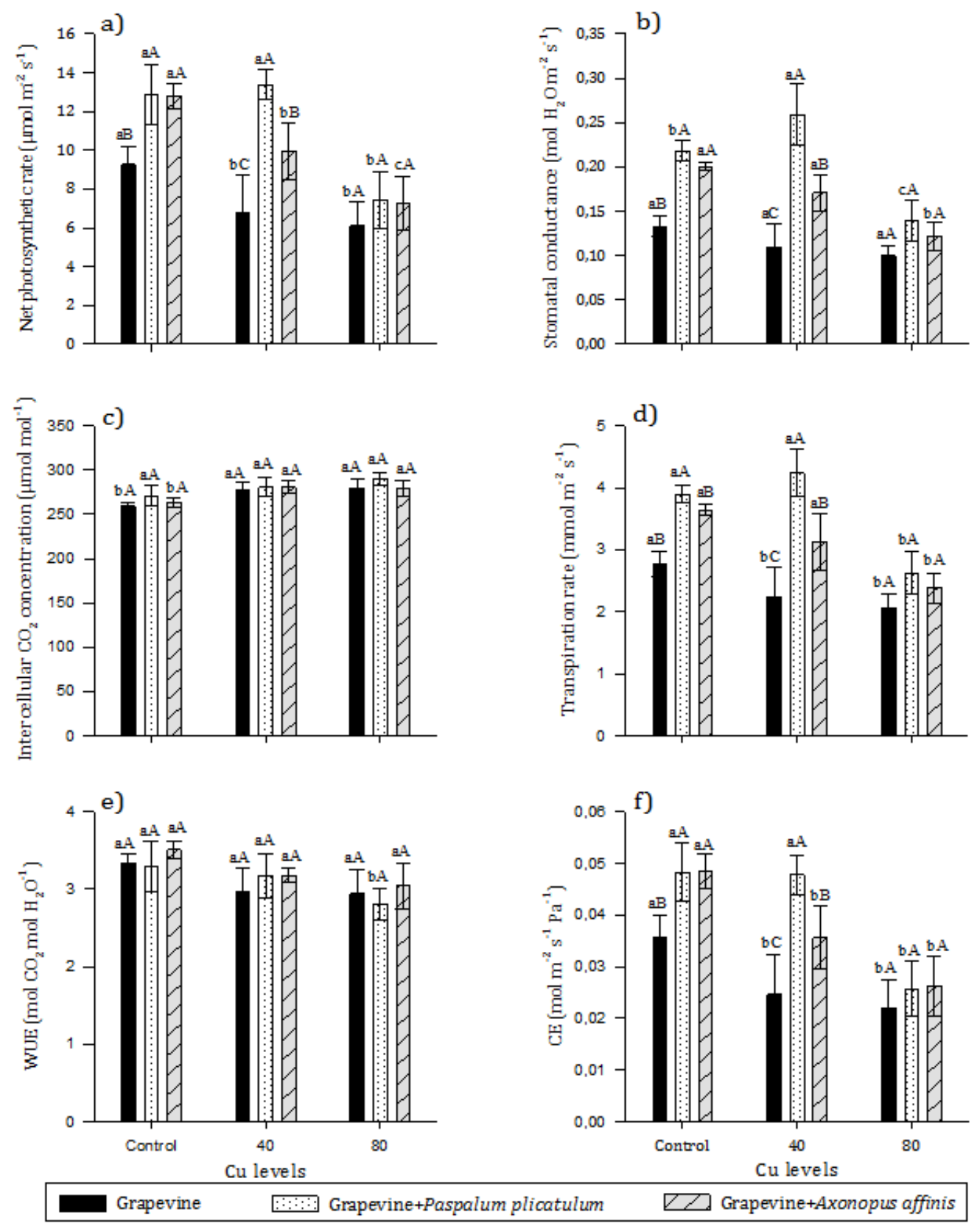

Figure 1. a) Net photosynthetic rate, b) stomatal conductance, c) intercellular $\mathrm{CO}_{2}$ concentration, d) transpiration rate, e) water use efficiency and f) instantaneous carboxylation efficiency of young grapevines. Means followed by the same lowercase letter do not differ between $\mathrm{Cu}$ levels in the same cropping system. Means followed by the same uppercase letter do not differ between cropping systems in same Cu level (Scott-Knott test, $p<0.05$ ). 

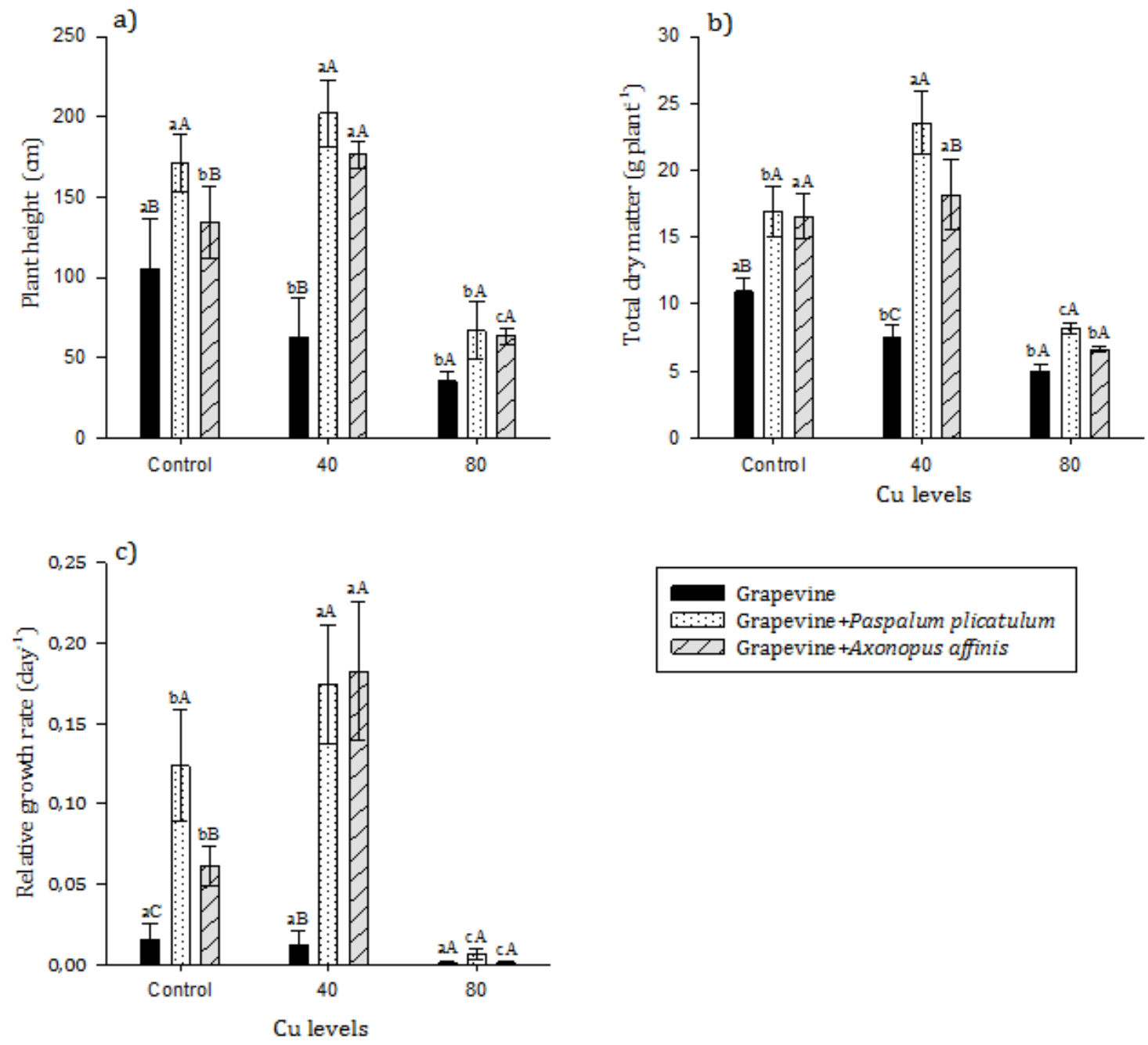

Figure 2. a) Plant height, b) dry matter yield, and c) relative growth rate of young grapevines. Means followed by the same lowercase letter do not differ between $\mathrm{Cu}$ levels in the same cropping system. Means followed by the same uppercase letter do not differ between cropping systems at the same Cu level (Scott-Knott test, $p<0.05$ ).

\section{CONCLUSION}

The addition of $\mathrm{Cu}$ caused phytotoxicity in the single crop (Grapevine), reducing photosynthetic carbon assimilation and plant growth. The cultivation of young grapevines intercropped with native grasses, especially Paspalum plicatulum Michx., promoted the growth of the grapevines in the control soil as well as in the moderately Cu-contaminated soils. This indicates that maintaining native vegetation in young vineyards can reduce $\mathrm{Cu}$ toxicity to transplanted grapevines.

\section{ACKNOWLEDGEMENTS}

We would like to thank the National Scientific and Technological Development Council (CNPq) and the Research Support Foundation of Rio Grande do Sul (Fundação de Amparo a Pesquisa do Estado do Rio Grande do Sul - Fapergs) for the financial support in this research project. 


\section{Literature cited}

Brunetto, G., Bastos de Melo, G.W., Terzano, R., Del Buono, D., Astolfi, S., Tomasi, N., Pii, Y., Mimmo, T., and Cesco, S. (2016). Copper accumulation in vineyard soils: rhizosphere processes and agronomic practices to limit its toxicity. Chemosphere 162, 293-307 https://doi.org/10.1016/j.chemosphere.2016.07.104. PubMed

Cambrollé, J., García, J.L., Figueroa, M.E., and Cantos, M. (2015). Evaluating wild grapevine tolerance to copper toxicity. Chemosphere 120,171-178 https://doi.org/10.1016/j.chemosphere.2014.06.044. PubMed

De Conti, L., Ceretta, C.A., Ferreira, P.A.A., Lourenzi, C.R., Girotto, E., Lorensini, F., Tiecher, T.L., Marchezan, C., Anchieta, M.A., and Brunetto, G. (2016). Soil solution concentrations and chemical species of copper and zinc in a soil with a history of pig slurry application and plant cultivation. Agric. Ecosyst. Environ. 216, 374-386 https://doi.org/10.1016/j.agee.2015.09.040.

Ferreira, D.F. (2011). SISVAR: a computer statistical analysis system. Ciencia E Agrotecnologia 35 (6), 1039-1042 https://doi.org/10.1590/S1413-70542011000600001.

Kabata-Pendias, A. (2011). Trace Elements in Soils and Plants (Boca Ratón, Florida: CRC Press).

Maksymiec, W., Bednara, J., and Baszynski, T. (1995). Responses of runner plants to excess copper as a function of plant growth stages: effects on morphology and structure of primary leaves and their chloroplast ultrastructural. Photosynthetica 31, 427-435.

McBride, M.B. (1994). Environmental Chemistry of Soils (New York: Oxford University Press), pp.406.

Miotto, A., Ceretta, C.A., Brunetto, G., Nicoloso, F.T., Girotto, E., Farias, J.G., Tiecher, T.L., De Conti, L., and Trentin, G. (2014). Copper uptake, accumulation and physiological changes in adult grapevines in response to excess copper in soil. Plant Soil 374 (1-2), 593-610 https://doi.org/10.1007/s11104-013-1886-7.

Oyuela Leguizamo, M.A., Fernández Gómez, W.D., and Sarmiento, M.C.G. (2017). Native herbaceous plant species with potential use in phytoremediation of heavy metals, spotlight on wetlands - A review. Chemosphere 168, 1230-1247 https://doi.org/10.1016/j.chemosphere.2016.10.075. PubMed

Pallarés, O.R., Barreta, E.J., and Marasching, G.E. (2005). The South American Campos ecosystem. In Grasslands of the World, J.M. Suttie, S.G. Reynolds, and C. Batello, eds. (Rome: FAO), p.171-219.

Sieverding, E. (1991). Vesicular-Arbuscular Mycorrhiza Management in Tropical Agrosystems (Eschborn, Germany: Deutsche Gesellschaft für Technisch Zusammenarbeit), pp.371.

Soil Survey Staff-SOIL TAXONOMY. (2006). A Basic System of Soil Classification for Making and interpreting Soil Surveys, $2^{\text {nd }}$ edn (Washington: US Government Printing Office), pp.333.

Tiecher, T.L., Tiecher, T., Ceretta, C.A., Ferreira, P.A.A., Nicoloso, F.T., Soriani, H.H., Tassinari, A., Paranhos, J.T., De Conti, L., and Brunetto, G. (2016). Physiological and nutritional status of black oat (Avena strigosa Schreb.) grown in soil with interaction of high doses of copper and zinc. Plant Physiol. Biochem. 106, 253-263 https://doi.org/ 10.1016/j.plaphy.2016.05.015. PubMed 